\title{
Reflexões acerca da possibilidade da Prisão Civil do Depositário Judicial Infiel e Tutela Jurisdicional Efetiva
}

\author{
Considerati on Civil Prison of Judicial \\ Dishonest Bailee AND EfFective \\ Jurisdictional Protection
}

\author{
Douglas Henrique de Oliveira * \\ Silvia Regina Tacla **
}

Resumo: Trata-se de trabalho desenvolvido com o fim de investigar a possibilidade da decretação da prisão civil do depositário judicial infiel. Para tanto, pretende-se demonstrar sua viabilidade, por meio da distinção do instituto de outras modalidades de depósito, bem como a ausência de conflito com normas constitucionais e internacionais de Direitos Humanos. Com isso, busca-se proporcionar um espaço para debater o texto da Súmula Vinculante ${ }^{\circ} 25$, a qual extinguiu o instituto do sistema jurídico, tendo como norte o princípio da tutela jurisdicional efetiva ou acesso à justiça.

Palavras-chave: Tutela jurisdicional efetiva, acesso à justiça, prisão civil, depositário, depositário infiel, depositário judicial infiel.

Abstract: This is a paper developed to investigate the possibility of decreeing the civil prison for judicial dishonest bailee. For this, it is intended to evidence its feasibility through distinction of institution from other bailment modalities, as well as the absence of conflict with constitutional and international rules of Human Rights. Therefore, the goal is to provide a space to discuss the text from Binding Abridgement nr. 25, which has eliminated the institution from juridical system, having as North the principle of effective jurisdictional protection or accesses to justice.

Keywords: Effective jurisdictional protection, access to justice, civil prison, bailee, dishonest bailee, judicial dishonest bailee.

\section{Universidade Estadual de Lon-} drina (1988) e mestrado em Direito pela Universidade de Marília (2002). Professora titular da Universidade Estadual de Londrina, no departamento de direito público. E-mail: silviatacla@uel.br
* Pós-graduando em Direito Universidade Estadual de Londrina (2011). E-mail: douglasoliveira@sercomtel.com.br ** Graduação em Direito pela

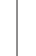




\section{INTRODUÇÃO}

Não são raros os casos em que, depois de uma árdua e longa batalha judicial, o credor se vê frustrado pelo fato de ter o executado se tornado intencionalmente insolvente após a penhora de bens do seu patrimônio. A situação, além de injusta, não pode persistir.

Não se trata apenas de uma busca de medidas que atendam o anseio do que se venha a entender como justo no caso concreto. O Estado, ao tomar para si o poder de mediar conflitos, assume um dever de satisfazer efetivamente os direitos violados em busca do reequilíbrio das relações sociais.

É a busca por uma solução definitiva que motiva o cidadão em bater à porta do judiciário e este, após o devido processo legal, deve proporcionar meios para que sua decisão não seja meramente opinativa. Suas decisões devem ir além e ser realmente efetivas, reais, existirem de fato.

É no intuito de contribuir para o aprimoramento das técnicas que viabilizam a tutela jurisdicional efetiva, elencada à condição de Direito Fundamental pelo artigo $5^{\circ}, \mathrm{XXXV}$ da Constituição Federal, também denominada de acesso à justiça, que se pretende desenvolver reflexões acerca da prisão civil do depositário judicial infiel.

Para fins propedêuticos, pode-se dizer que se trata de um instituto jurídico de direito público, passível de utilização durante a fase executória do processo civil e trabalhista, mas que fora proibido pela Súmula Vinculante n ${ }^{\circ} 25$ do Supremo Tribunal Federal, editada em 16 de Dezembro de 2009 e publicada em 12 de Fevereiro de 2010.

Conforme se observará no decorrer desse trabalho, não obstante o respeitável posicionamento da Corte Suprema, existem razões que levam a crer que a prisão civil no caso do depositário judicial infiel é juridicamente possível e não encontra óbice em norma de direito interno ou internacional.

Assim, com o desenvolver desse trabalho, pretende-se não apenas satisfazer requisitos formais para a obtenção de um título acadêmico, mas também fortalecer a ideia da possibilidade de repensar a Súmula Vinculante $n^{\circ} 25$, a fim de disponibilizar mais um meio para que o cidadão possa ter ser direito violado efetivamente satisfeito pelo Judiciário.

Para tanto, serão abordadas questões atinentes a diversos ramos da Ciência Jurídica, como o Direito Constitucional, Processual Civil, Civil, Internacional Público e a própria Teoria Geral do Direito e do Processo, de onde se extrairão as primeiras e fundamentais noções para situar e problematizar o tema proposto. 


\section{CONFLITOS SOCIAIS E TUTELAJURISDICIONAL EFETIVA}

O esforço de refletir acerca da possibilidade da prisão civil do depositário judicial infiel é uma tarefa a qual poderia contemplar a construção de um raciocínio lógico-jurídico tão somente a partir da análise das normas vigentes no ordenamento jurídico brasileiro.

No entanto, pensa-se que a questão, em um primeiro plano, deve ser analisada sob a ótica do fortalecimento do Estado Moderno e a assunção de um papel junto a solução de conflitos sociais por meio da atividade jurisdicional, no intuito de compreender o cerne do compromisso firmado e seus respectivos desdobramentos, tarefa essa que passa a ser desempenhada.

\subsection{Direito e sociedade}

No estágio atual dos conhecimentos desenvolvidos acerca da Ciência Jurídica, é predominante o entendimento de que o Direito existe para regular a sociedade, conforme a notória lição de Ulpiano, que proclamara que onde houvesse sociedade, haveria Direito.

Ademais, por mais que existam os que sustentem uma fase em que o ser humano vivesse isolado, há consenso no sentido de que a convivência em sociedade sempre foi a regra, pois as necessidades vitais e intelectivas só poderiam ser satisfeitas em contato com semelhantes (SILVA, 2003, p.1).

Justamente por isso, é difícil imaginar na história humana um período em que o ser humano não tivesse feito uso do Direito, mesmo em formato rudimentar, para proporcionar harmonia em seu meio, já que o conflito, sem se ater às correntes filosóficas pertinentes, sempre pareceu inerente a vida em sociedade.

A maneira pela qual age o Direito já é conhecida, antes mesmo de qualquer contato que se possa ter com o estudo do universo jurídico. O Direito, em uma de suas acepções, diz respeito a todas as normas legais e vigentes em determinado tempo e espaço.

[...] o direito objetivo vai preestabelecer padrões de condutas a serem observados pelas pessoas, através de normas gerais, abstratas e abrangentes, quer nas relações entre si, como nas relações com os bens da vida, sem neutralizar ou castrar iniciativas consideradas sadias, mas canalizá-las para a convivência pacífica (PANCOTTI, 2002, p.21).

Essa finalidade, denominada por sociólogos como ROSA (2009, p. 123) de 'meta cultural', a qual é atribuída ao Direito, é ponto consensual na doutrina, 
a qual procura deixar claro que o mundo sem ele seria tomado pela violência e a lógica do mais forte.

É pacífico e incontestável o entendimento de que a paz social é proporcionada pela presença do direito no seio da sociedade. Este é o papel, a principal função do ordenamento jurídico. É nesse sentido que a instituição jurídica ingressa com toda altivez no corpo social, controlando o comportamento humano e harmonizando as relações intersubjetivas (SILVA, 2003, p.3).

Para tanto, o Direito instrumentaliza os valores fundamentais e as principais decisões políticas realizadas pela sociedade, em clara demonstração de que a observância do fato social jamais deve se distanciar do mundo jurídico.

A tarefa da ordem jurídica é exatamente a de harmonizar as relações sociais intersubjetivas, a fim de ensejar a máxima realização dos valores humanos com o mínimo de sacrifício e desgaste. O critério que deve orientar essa coordenação ou harmonização é o critério do justo e do equitativo, de acordo com a convicção prevalente em determinado momento e lugar (CINTRA, 2009, p.5).

Entretanto, muitas vezes o simples enunciado de uma norma jurídica não surte o efeito desejado para regular as condutas na sociedade, razão pela qual se busca instrumentos para fazer valer a vontade trazida na lei.

A existência do direito regulador da cooperação entre pessoas [...] não é, porém, suficiente para evitar ou eliminar os conflitos que podem surgir entre elas. Esses conflitos caracterizam-se por situações em que uma pessoa, pretendendo para si determinado bem, não pode obtê-lo [...] (CINTRA, 2009, p.26).

É a respeito da formação e configuração dessa situação de conflito que se passa a tecer breves comentários a partir de agora com o intuito de compreender, com algum grau de profundidade, o papel do Direito na realização da pacificação social.

\subsection{Os conflitos sociais como objeto do Direito}

Conforme se prenunciou acima, o ser humano possui não apenas uma tendência natural, mas também uma necessidade de viver em sociedade, o que, eventualmente ocasiona conflitos. Isso porque é um animal complexo e de necessidades múltiplas, que precisam ser satisfeitas com os bens naturais e artificiais existentes no mundo.

No mesmo sentido, doutrina Ugo Rocco, para quem bem é tudo o que é apto para satisfazer ou que satisfaz a uma necessidade. A amplitude do conceito permite que ele compreenda tanto bens materiais (água, alimento, vestuário e transporte) como imateriais (paz, liberdade, honra e amor) (ALVIM, 2008, p.3). 
Emerge daí o conceito de interesse, que, de modo simplificado, pode ser entendido como o potencial de um bem em satisfazer uma necessidade, ou, como prefere, mais uma, vez ROCCO (apud ALVIM, 2008, p. 8), o juízo formulado por um sujeito acerca de uma necessidade, sobre a utilidade de um bem enquanto meio para a satisfação de uma necessidade.

Como os bens são limitados, ao contrário das necessidades humanas, que são ilimitadas, surge entre os homens, relativamente a determinados bens, choques de forças que caracterizam o conflito de interesses, e os conflitos são inevitáveis no meio social.

Em realidade, o processo de conflito é observável em todas as manifestações da vida social. Está presente nos diversos tipos de sociedade, das mais simples às mais complexas, de modo que é possível afirmar que inexiste sociedade em que ele não apareça. O entrechoque de interesses, entendidos na sua significação mais simples, manifestando-se numa escala de mera vivência ou, mais especialmente, em fenômeno de poder, de apropriação de recursos ou de relacionamentos preferenciais, revela situações em que o conflito se faz atuante (ROSA, 2009, p.66).

Por possuir particular importância para a sociedade, a mente humana, ao longo do tempo, buscou construir formas de solucionar esses conflitos, não obstante a existências das normas de conduta a que se fez alusão na primeira parte desse trabalho, e o Direito, naturalmente, foi o meio pensado para essa tarefa.

\subsection{Evolução histórica das espécies de solução de conflitos sociais}

Um breve olhar para a história revela que um longo caminho foi percorrido no que se refere aos métodos de resolução de conflitos hoje existentes. Em síntese, percebe-se que a eliminação do conflito se realizou por obra de um ou de ambos os sujeitos dos interesses conflitantes, ou por ato de terceiro.

O passado nos mostra que o primeiro método de solução de conflitos a que se tem notícia, foi a autotutela, caracterizada pelo predomínio da força e imposição de um interesse sobre o outro (SANTOS, 2008, p.4). É fácil perceber que era precária e aleatória, pois não garantia a justiça, mas a vitória do mais forte.

Além da autotutela, outra solução criada foi a autocomposição, oriunda dos sistemas primitivos, a qual consistia que uma das partes em conflito, ou ambas, abrissem mão do interesse ou de parte dele para a uma solução compreendida como razoável (CINTRA, 2009, p.27). 
Pouco a pouco, à medida que o Estado se afirma na história, a humanidade percebe que esses métodos os quais dependiam da vontade das partes envolvidas encontravam falhas, razão pela qual se passa a contar com terceiros ou árbitros imparciais para a solução dos conflitos.

Os árbitros eram, geralmente, pessoas mais velhas, com notória sabedoria e, o principal, de confiança recíproca. Em alguns casos, eram ligadas à igreja e, em outros, à determinada classe social ou laboral. Quanto a isto, é de grande relevância notar a evolução dos efeitos dessas decisões.

Isso porque, com o fortalecimento do Estado e a ocupação de áreas que antes eram juridicamente de incumbência apenas dos particulares, o árbitro passa a ser indicado pelo Estado, até ser substituído totalmente por juízes, e as decisões passam a ter efeitos vinculantes e coercitivos.

É nesse contexto que surge o processo, como um instrumento que proporciona a atuação de juízes que decidem, em substituição às partes e em observância à lei, os conflitos sociais, os quais passam a ser caracterizados pela presença de uma pretensão resistida, conforme as famosas anotações de Carnelutti, e juridicamente denominados de lide (MARINONI, 2010, p.37).

Nesse quadro é que avulta a grande valia social do processo como elemento de pacificação. O escopo de pacificar pessoas mediante a eliminação de conflitos com justiça é, em última análise, a razão mais profunda pela qual o processo existe e se legitima na sociedade (DINAMARCO, 2002, p.128).

Percebe-se, portanto, que a história mostra que o Estado construiu um mecanismo em substituição a Justiça Privada e, de certa forma, se compromete a proporcionar ao cidadão o mesmo resultado que ele obteria naquela, caso for observada a norma de direito substancial.

Dessa forma, a simples prestação jurisdicional tornou-se insuficiente. O Estado deve concedê-la de forma adequada, propiciando sua efetividade para compor o litígio de modo justo. Para isso, o Estado teve que criar instrumentos aptos a satisfazer eficazmente as pretensões a ele formuladas (MOTA, 2007, p.14).

Nesta perspectiva, a viabilização do acesso a uma ordem jurídica justa dar-se-á somente com a promoção de uma atividade jurídica qualificada. A inexistência de tutela adequada às situações conflitivas impostas ao Estado, significa a própria denegação de Justiça, razão pela qual a tutela jurisdicional deve, dentro do aceitável, buscar o maior grau de efetividade possível.

\subsection{Tutela jurisdicional efetiva e pacificação social}

A tutela jurisdicional efetiva, também denominada por alguns de princípio do acesso à justiça, princípio da inafastabilidade ou direito de ação, é uma norma 
que possibilita que todos, indistintamente, possam pleitear os seus direitos junto ao Poder Judiciário, desde que obedecidas as regras estabelecidas pela legislação processual pertinente para o exercício desse direito.

Essa conceituação, de aspecto notadamente formal, é inspirada no ideal liberal, que propulsionou a construção desse princípio, sobretudo para que os cidadãos burgueses pudessem fazer uso de órgãos judiciais para pleitear suas demandas (ACIOLI, 2011, p.70).

Essa concepção, predominante na história do direito, inspirou e se fez presentes em todos os textos constitucionais brasileiros e recebeu novos contornos por ocasião da Constituição Federal de 1988, a qual fortaleceu uma série de iniciativas que propunham a efetivação de direitos.

Com isso, a tutela jurisdicional, até então arraigada à noção da possibilidade de peticionar, expandiu-se e seu significado passou a se aproximar da preocupação com a efetividade processual, traduzida como a busca pelo que é real, verdadeiro, o que existe de fato.

Processo efetivo é aquele apto a entregar, com o máximo de proveito e adequação, a tutela jurisdicional a quem, por meio do processo, resulte merecedor da resposta do Estado-Juiz, aproximando-se ao máximo da realização que o direito material atribui a quem o titularize.[...] Ela não pode ser estudada como um simples exercício da jurisdição com entrega do provimento jurisdicional. De fato, deverá ser entendida como efetivação de direitos (MOTA, 2007, p.57).

Assim, a norma esculpida no artigo $5^{\circ}, \mathrm{XXXV}$ da Constituição Federal, a qual menciona que a lei não excluirá da apreciação do Poder Judiciário, lesão ou ameaça a direito, passa a traduzir não apenas a preocupação com a prolação de uma sentença ou a observância das normas técnicas que descrevem o processo judicial, mas também a criação de meios para a realização efetiva do direito do jurisdicionado.

Diferente é o posicionamento moderno, agora girando em torno da ideia do processo civil de resultados. Consiste esse postulado na consciência de que o valor de todo sistema processual reside na capacidade, que tenha, de propiciar ao sujeito que tiver razão uma situação melhor do que aquela em que se encontrava antes do processo. Não basta o belo enunciado de uma sentença bem estruturada e portadora de afirmações inteiramente favoráveis ao sujeito, quando o que ela dispõe não se projetar utilmente na vida deste, eliminando a insatisfação que o levou a litigar e propiciando-lhe sensações felizes pela obtenção da coisa ou da situação postulada (DINAMARCO, 2002, p.108). 
Sendo assim, é inegável a validade do esforço aqui desenvolvido no sentido de refletir sobre a possibilidade da prisão civil do depositário judicial infiel, pois a sua proibição, por força da Súmula Vinculante $n^{\circ} 25$ do Supremo Tribunal Federal, retirou um forte instrumento à disposição pelo poder judiciário para buscar a satisfação dos direitos do cidadão.

Por outro lado, é cediço reconhecer as dificuldades, pois diz respeito à intromissão na órbita individual do particular por meio da restrição de sua liberdade de locomoção. No entanto, todo esforço interpretativo deve ser dirigido à efetividade da tutela jurisdicional, em nome do compromisso assumido pelo Estado, pois o processo não pode ser tido como uma inesgotável fonte de decepções.

Feitas essas considerações, é necessário trazer à tela o tema, a fim de analisar como está caracterizada a prisão civil no ordenamento jurídico, sua aplicação ao depositário infiel, a devida distinção desta com as outras modalidades de depósito, para então refletir sobre o que gerou sua proibição por meio da súmula vinculante.

\section{PRISÃO CIVIL E DEPOSITÁRIO INFIEL NO DIREITO BRASILEIRO}

Até o presente momento, procurou-se demonstrar que o Direito, historicamente, surge com a função de proporcionar a pacificação social, pois a vida em sociedade naturalmente gera conflitos, e que hoje, com o fortalecimento do Estado, este toma pra si não só a responsabilidade de solucionar os conflitos, mas também de proporcionar o exercício efetivo do direito violado.

Esse exercício efetivo, real, positivo do direito, declarado pelos órgãos judiciais, nem sempre se realiza de maneira pacífica. Em boa parte dos casos, o devedor do bem ou obrigação se refuta a cumprir o mandamento judicial voluntariamente, oportunidade na qual surge para o credor o direito de fazer da, a partir de agora tratada, tutela executiva.

Essa modalidade [...] está diretamente relacionada - e quase sempre restrita - às crises de cooperação, quando a atuação da norma concreta se faz mediante a realização de sanções que incidem sobre o mundo dos fatos, com ou sem a colaboração do vencido que, até então, recusou-se a cooperar cumprindo o dever ou obrigação representados no título executivo (ABELHA, 2009, p.6).

É nesse contexto que se faz presente o instituto da prisão civil do depositário judicial infiel, e é na consecução desse objetivo, o da busca da 
realização efetiva do direito declarado pelo órgão judicial, que sua existência deve ser objeto de reflexão nesse trabalho.

No entanto, sua devida abordagem perpassa, necessariamente, pela consideração prévia de alguns conceitos basilares que compõe a própria terminologia do instituto, e é esse o esforço que passa a ser desenvolvido.

\subsection{Prisão Civil: delimitação conceitual}

Antes de se questionar o que vem a ser prisão civil, é elementar que se reflita sobre a palavra prisão. Em uma de suas acepções, de origem no latim, do termo vulgar prensione, derivado do latim clássico prehensione, significa ato ou efeito de prender, ou ato pelo qual a pessoa fica privada de sua liberdade de locomoção (DICIONÁRIO JURÍDICO BRASILEIRO, 2012).

Basicamente, quer dizer a privação do direito fundamental de liberdade de locomoção, ou seja, de ir e vir, conforme ordem legal ou em virtude de fato praticado pelo particular que possua como reflexo no ordenamento jurídico a pena de prisão, ou seja, tipificação como crime (SÁ, 2012).

Partindo dessa ideia, é possível estabelecer por meio da conjugação de termos, que a prisão civil pode ser entendida como a privação da liberdade de locomoção em virtude de ordem judicial que possua como fundamento a ocorrência de fato jurídico não ligado a esfera Penal.

A conceituação pode soar um pouco abstrata, mas parte da própria divisão que a Ciência do Direito faz entre Direito Penal e Direito Civil, de modo a fazer constar nesse, não só os assuntos diretamente ligados às questões privadas, mas os que residualmente não podem ser encaixados no Direito Penal.

Outrossim, há de se constatar que a afirmação proposta não possui a abrangência que leva a crer, pois, como se observará no decorrer deste trabalho, as condutas que chegaram ou chegam a ser repreendidas com a prisão civil são reconhecidamente restritas.

Por fim, e como já se pode imaginar, a prisão civil não é instituto atual. Possui grande bagagem histórica, e no passado fora fortemente associada a uns dos meios concebidos pelo Direito para a solução de conflitos, a autotutela, o que merece algumas considerações.

\subsection{Aspectos históricos da prisão civil}

Antes que se possam realizar algumas digressões históricas, é importante frisar que durante muito tempo a prisão civil, seja em razão de dívidas, seja em 
razão de contrato de depósito, deposito judicial ou verba alimentar, existiu de modo usual. Só com o passar dos tempos começou a haver um corte, no sentido de permiti-la apenas em algumas situações, conforme se observará.

As primeiras formas de resolução de conflitos encontradas pelo ser humano eram baseadas na justiça privada e possuíam grande caráter retributivo, para devolver o mal causado pelo devedor, e educativo, ao funcionar como pressão psicológica para que toda a sociedade não tentasse cometer os mesmos erros FREITAS, 2012).

Justamente de encontro com essa ideia é possível firmar o surgimento da prisão civil. Quanto a isso, há quem ressalte o legado do Código de Hamurabi e das leis do antigo Egito, que possibilitavam o recolhimento do devedor à prisão diante de dívida não paga.

No entanto, é certo, que o maior marco histórico do instituto está no Direito Romano, mais precisamente, na lei das XII Tábuas, que em sua tábua terceira, nas leis de IV a IX, dispunha a possibilidade de realização de castigos corporais, escravidão e esquartejamento, caso houvesse concurso de credores e ninguém comprasse o devedor depois de apregoado em três feiras, situação que começou a mudar ainda na antiguidade (SÁ, 2012).

Mas ainda antes de Cristo, essa admissão caiu por terra. A Lex Poetelia Papiria, oriunda de um levante contra os maus tratos aplicados a um devedor plebeu, reformulou-a determinando que a execução da dívida recaísse sobre o patrimônio, muito embora os débitos oriundos de delito pudessem levar à escravidão do devedor. E isso no ano de 326 a.C (QUEIROZ, 2004, p.116).

A idade média, conhecida por alguns retrocessos em questões culturais, também ficou marcada pela volta a prática da prisão civil por dívida, realidade que só se alterou a medida que os povos retomaram as lições já pregadas pela Lex Poetelia Papiria, o que aconteceu por ocasião do Código Civil Francês de 1804 e em outros diplomas a partir dessa data.

Já no cenário brasileiro, a prisão civil surgiu já com a colonização portuguesa, por força das ordenações afonsivas, manuelinas e filipinas, que só foram revogadas pelo Código Civil de 1916, as quais estipulavam que, após a execução de todos os bens do devedor, poderia o juiz determinar a retenção do mesmo até que fosse pago todo o seu débito (QUEIROZ, 2004, p.118).

Após deixar a condição de colônia portuguesa, o Brasil passou um longo período até que a prisão civil recebesse um marco jurídico satisfatório, sobretudo em nível constitucional.

Quanto às disposições constitucionais a respeito desse instrumento de coerção, devemos lembrar que a Constituição Política do Império do Brasil de 
25.03.1824, bem como a Constituição da República dos Estados Unidos do Brasil de 24.01.1891, foram omissas a respeito. A Constituição de 16.07.1934 foi incisiva, não admitiu exceções quando em seu artigo 113, n. 30, decretava "que não existirá prisão por dívidas, multas ou custas". Já a Constituição de 1937 deixa à legislação ordinária a questão da prisão por dívida, não oferecendo garantia contra a mesma. As Constituições de 18 de setembro de 1946 e de 24 de Janeiro de 1967 e a Emenda Constitucional n. 1 de 17.10.1969 excepcionaram o devedor de alimentos e o depositário infiel, com uma redação bem semelhante (QUEIROZ, 2004, p.120).

Em âmbito infraconstitucional, tanto o Código Civil de 1916, como o de Processo Civil de 1939, reiteram as disposições constitucionais vigentes à época e começaram a aprofundar, aos poucos, a distinção entre as modalidades de prisão civil, o que se consolidou de vez no diploma processual vigente.

O Código de Processo Civil de 1973 distingue muito claramente as figuras do depositário contratual e do depositário judicial, atribuindo a este último a função de auxiliar da justiça (arts. 139 e 148/150), o que denuncia o múnus público por si desempenhado no exercício daquele mister, agastando do âmbito do direito privado aquela relação jurídica assumida para, indubitavelmente, introduzi-la na seara do direito público (ACIOLI, 2011, p.25).

Como não poderia ser diferente, a Constituição Federal de 1988 disciplina a questão em seu artigo $5^{\circ}$, LXVII, o qual assegura que "não haverá prisão civil por dívida, salvo a do responsável pelo inadimplemento voluntário e inescusável de obrigação alimentícia e a do depositário infiel", e consolida a regra da proibição da prisão civil por dívida, e da possibilidade excepcional da prisão do alimentante e do depositário infiel, sobre o qual se passa a estudar.

\subsection{Depositário infiel: linhas gerais}

Não obstante a aparente tranquilidade que tenta transmitir o texto constitucional, a delimitação da exceção "depositário infiel" é tarefa das mais complexas dentro do Direito Constitucional. Isso porque o termo possui certa abrangência e abarca mais de uma situação em que haja o ato de depositar em contrapartida do ato de zelar pelo bem.

Por isso mesmo, é importante que se faça a devida distinção entre as modalidades existentes, já que a sugerida noção supra, ainda que se considere sua origem - do latim, "deponere", que designa pessoa a quem se entrega ou a quem se confia alguma coisa em depósito - é singela e está claramente desprovida de cientificidade jurídica buscada (SOUZA, 2012). 
A doutrina, em geral, noticia a existência de algumas modalidades de depositário infiel, ao abarcar no gênero o depósito judicial, a alienação fiduciária, o contrato de depósito, o depósito do hoteleiro, o depósito da fazenda pública, o depósito mercantil, dentre outros.

Entretanto, tanto para fins desse trabalho como por questões didáticas, é possível reunir características comuns desses institutos e agrupá-los em dois grupos: o depositário infiel em razão de infração à norma de direito material ou de direito privado e o em razão de infração à norma de direito processual ou de direito público.

No primeiro grupo, é possível alocar, como o nome sugere, as modalidades de depósito oriundas de relação privada, em que a dívida é o principal elemento a determinar a decretação da prisão civil. É aqui que se fazem presentes o contrato de depósito e a alienação fiduciária, o depósito do hoteleiro ou hospedeiro, o depósito da fazenda pública e o depósito mercantil.

Já no segundo grupo, encontram-se as hipóteses em que a prisão civil ocorre em virtude de infração à norma de direito público, caso que envolve o depositário judicial, um múnus que pode recair sobre qualquer cidadão e que o torna um auxiliar da justiça, que guarda, conserva e, por vezes, administra os bens penhorados, por ordem dos órgãos judiciais, conforme redação do artigo 148 do Código de Processo Civil (SANTOS, 2008, p.326).

No intuito de regular o múnus desse cidadão, o Código de Processo Civil, alterado pela lei 11.382/06, na esteira do que já declarava a súmula 619 do Supremo Tribunal Federal, disciplinou suas obrigações e instituiu inclusive a possibilidade da decretação da prisão civil por violação ao compromisso firmado, o qual ocorre principalmente quando o depositário é o próprio devedor.

Art. 666. Os bens penhorados serão preferencialmente depositados:

$[\ldots]$

II - em poder do depositário judicial, os móveis e os imóveis urbanos;

III - em mãos de depositário particular, os demais bens, na forma prescrita na Subseção V deste Capítulo.

III - em mãos de depositário particular, os demais bens.

$\S 1^{\circ}$ Com a expressa anuência do exeqüente ou nos casos de difícil remoção, os bens poderão ser depositados em poder do executado.

$[\ldots]$

$\S 3^{\circ}$ A prisão de depositário judicial infiel será decretada no próprio processo, independentemente de ação de depósito (grifo nosso).

Acerca do tratamento conferido ao depositário judicial infiel e já atento as devidas distinções que a matéria deve receber no que tange a possibilidade de prisão civil, se posiciona a doutrina: 
Assim, a prisão do depositário infiel é civil porque aplicada em processos submetidos à jurisdição civil ou não penal, mas, verdadeiramente, não possui qualquer vinculação com a dívida em execução, na medida em que decorre do descumprimento dos encargos oriundos de uma relação jurídica intraprocessual e de direito público que se forma entre o custode e o Estado/juiz, a qual não pode ser olvidada, negligenciada ou minorada na compreensão da problemática em questão (ACIOLI, 2011, p.57).

No entanto, não obstante a devida distinção entre os dois grupos dentro do instituto da prisão civil do depositário infiel, e a própria Constituição Federal vincular a vedação da prisão civil à dívida, a posição que predomina no cenário atual se situa em sentido diverso.

\subsection{Súmula Vinculante n⿳0 25 e vedação da prisão civil do depositário infiel}

A Emenda Constitucional n ${ }^{\circ} 45 / 04$ promoveu alterações significativas na estrutura, organização e fiscalização do Poder Judiciário. Dentre essas, certamente se faz presente a criação da súmula vinculante, concebida com o intuito de conferir idêntico tratamento a matérias reiteradamente discutidas, em atenção ao próprio princípio da segurança jurídica.

Nesse sentido, o artigo 103-A da Constituição Federal, posteriormente regulamentado pela lei 11.417/06, passou a dispor que caberia ao Supremo Tribunal Federal, observado o procedimento legal, editar as referidas súmulas as quais vinculariam todos os poderes constitucionais, em todos os níveis, no tocante à interpretação e eficácia de determinadas normas jurídicas.

Imbuído dessa nova competência constitucional, e após discussões realizadas por ocasião de alguns recursos, o Supremo Tribunal Federal, buscando conferir interpretação ao artigo $5^{\circ}$, LXVII da Constituição Federal, editou, em 16.12.09, a Súmula Vinculante $\mathrm{n}^{\mathrm{0}} 25$ para demarcar um norte para a questão da prisão civil do depositário infiel, a qual, publicada, passou a vigorar com o seguinte texto:

É ilícita a prisão civil do depositário infiel, qualquer que seja a modalidade do depósito.

Ainda no tocante à súmula, aprovada por unanimidade pelo plenário do Supremo Tribunal Federal, vale ainda trazer à discussão os dois recursos, que, conforme a própria ata da sessão que deliberou sobre a súmula vinculante, ensejaram sua edição e aprovação. São eles, o Recurso Especial n 349.703 do Rio Grande do Sul e o n 466.343 de São Paulo, cujas ementas seguem abaixo: 
PRISÃO CIVIL DO DEPOSITÁRIO INFIEL EM FACE DOS TRATADOS INTERNACIONAIS DE DIREITOS HUMANOS. INTERPRETAÇÃO DA PARTE FINAL DO INCISO LXVII DO ART. 5O DA CONSTITUIÇÃO BRASILEIRA DE 1988. POSIÇÃO HIERÁRQUICONORMATIVA DOS TRATADOS INTERNACIONAIS DE DIREITOS HUMANOS NO ORDENAMENTO JURÍDICO BRASILEIRO. Desde a adesão do Brasil, sem qualquer reserva, ao Pacto Internacional dos Direitos Civis e Políticos (art. 11) e à Convenção Americana sobre Direitos Humanos Pacto de San José da Costa Rica (art. $7^{\circ}, 7$ ), ambos no ano de 1992, não há mais base legal para prisão civil do depositário infiel, pois o caráter especial desses diplomas internacionais sobre direitos humanos lhes reserva lugar específico no ordenamento jurídico, estando abaixo da Constituição, porém acima da legislação interna. O status normativo supralegal dos tratados internacionais de direitos humanos subscritos pelo Brasil torna inaplicável a legislação infraconstitucional com ele conflitante, seja ela anterior ou posterior ao ato de adesão. Assim ocorreu com o art. 1.287 do Código Civil de 1916 e com o Decreto-Lei $n^{\circ}$ 911/69, assim como em relação ao art. 652 do Novo Código Civil (Lei ${ }^{\circ}$ 10.406/2002). ALIENAÇÃO FIDUCIÁRIA EM GARANTIA. DECRETO-LEI N 911/69. EQUIPAÇÃO DO DEVEDOR-FIDUCIANTE AO DEPOSITÁRIO. PRISÃO CIVIL DO DEVEDOR-FIDUCIANTE EM FACE DO PRINCÍPIO DA PROPORCIONALIDADE. A prisão civil do devedor-fiduciante no âmbito do contrato de alienação fiduciária em garantia viola o princípio da proporcionalidade, visto que: a) o ordenamento jurídico prevê outros meios processuais-executórios postos à disposição do credor-fiduciário para a garantia do crédito, de forma que a prisão civil, como medida extrema de coerção do devedor inadimplente, não passa no exame da proporcionalidade como proibição de excesso, em sua tríplice configuração: adequação, necessidade e proporcionalidade em sentido estrito; e b) o Decreto-Lei ${ }^{\circ}$ 911/ 69, ao instituir uma ficção jurídica, equiparando o devedor-fiduciante ao depositário, para todos os efeitos previstos nas leis civis e penais, criou uma figura atípica de depósito, transbordando os limites do conteúdo semântico da expressão "depositário infiel" insculpida no art. $5^{\circ}$, inciso LXVII, da Constituição e, dessa forma, desfigurando o instituto do depósito em sua conformação constitucional, o que perfaz a violação ao princípio da reserva legal proporcional. RECURSO EXTRAORDINÁRIO CONHECIDO E NÃO PROVIDO. (RE 349703, Relator(a): Min. CARLOS BRITTO, Tribunal Pleno, julgado em 03/ 12/2008, DJe-104 DIVULG 04-06-2009 PUBLIC 05-06-2009 EMENT VOL02363-04 PP-00675) (grifo nosso)

REVISTA DO DIREITO PÚBLICO, Londrina, v.8, n.1, p.189-214, jan./abr.2013 
EMENTA: PRISÃO CIVIL. Depósito. Depositário infiel. Alienação fiduciária. Decretação da medida coercitiva. Inadmissibilidade absoluta. Insubsistência da previsão constitucional e das normas subalternas. Interpretação do art. $5^{\circ}$, inc. LXVII e $\S \S 1^{\circ}, 2^{\circ}$ e $3^{\circ}$, da CF, à luz do art. $7^{\circ}, \S 7$, da Convenção Americana de Direitos Humanos (Pacto de San José da Costa Rica). Recurso improvido. Julgamento conjunto do RE $n^{\circ} 349.703$ e dos HCs $n^{\circ} 87.585$ e $^{\circ}$ 92.566. É ilícita a prisão civil de depositário infiel, qualquer que seja a modalidade do depósito. (RE 466343, Relator(a): Min. CEZAR PELUSO, Tribunal Pleno, julgado em 03/12/2008, DJe-104 DIVULG 04-06-2009 PUBLIC 05-06-2009 EMENT VOL-02363-06 PP-01106 RTJ VOL-00210-02 PP-00745 RDECTRAB v. 17, n. 186, 2010, p. 29-165) (grifo nosso).

A análise da ementa dos acórdãos supra, bem como de outras decisões onde matéria similar foi objeto de apreciação pelo Supremo Tribunal Federal, a exemplo do HC 87.585/TO, do 94.523/SP e do 96.234-3/MS, revela que o que respaldou a edição do enunciado do enunciado da Súmula Vinculante $n^{\circ} 25$ foi os casos de decretação de prisão civil do depositário infiel em razão de infração à norma de direito material ou privado, sobretudo, nos casos de contrato de depósito e alienação fiduciária.

Quanto a isso, não há dúvidas, pois o instituto da prisão civil dessa modalidade de depositário infiel realmente se colide com a vedação constitucional e as normas internacionais de Direitos Humanos, a que se fará alusão no momento oportuno. A respeito da questão, a própria doutrina é uníssona:

Nesse caso, não há dúvida de que a prisão do depositário civil decorre diretamente do descumprimento da sua obrigação contratual de restituir a coisa depositada, tratando-se de medida coercitiva que busca interferir na sua esfera subjetiva para fazê-lo adimplir o contrato, sendo bastante para essa inflexão a leitura da dicção do art. 652, do CC "Seja o depósito voluntário ou necessário, o depositário que não o restituir quando exigido será compelido a fazê-lo mediante prisão não excedente a um ano e ressarcir os prejuízos" (ACIOLI, 2011, p.48).

Portanto, caminhou bem o Supremo Tribunal Federal ao vedar esse tipo de decretação de prisão civil. No entanto, e em relação à ofensa às normas de direito processual, ou de caráter público, notadamente, no que se refere ao depositário judicial, acertou o notável órgão ao conferir a vedação em sentido genérico e compreender, na redação da súmula vinculante, qualquer modalidade do depósito? É o que se passa a estudar a partir de agora. 


\section{POSSIBILIDADE DA PRISÃO CIVIL DO DEPOSITÁRIO JUDICIAL INFIEL}

Conforme se observa logo no título desse capítulo, e até mesmo por meio das ideias que foram paulatinamente defendidas ao longo do texto, a prisão do depositário judicial infiel não só se mostra viável, como é medida de que atende ao ideal de tutela jurisdicional efetiva, ou acesso à justiça, exposto no primeiro capítulo.

Isso não só porque a Súmula Vinculante $\mathrm{n}^{\circ} 25$ não fez as distinções entre as modalidades de depósito para declaração da ilicitude da prisão civil, mas como também pelo posicionamento firmado pela Constituição Federal e as normas internacionais de Direitos Humanos, conforme se passa a investigar.

\subsection{Inobservância das modalidades de depósito para a adoção da redação da Súmula Vinculante n⿳0 25}

É possível se perceber que não foi objeto de apreciação pela Suprema Corte, quando da edição da Súmula Vinculante n. 25, a questão da natureza jurídica de direito público que repousa sobre a figura do depositário judicial de bens penhorados, conforme já relatado nesse trabalho.

Com isso, questões emblemáticas geradas pela conduta de devedores que se desfazem dos bens, mesmo depois de serem penhoradas, passaram a não receber o amparado merecido, aviltando a dignidade da justiça e o compromisso firmado com a tutela jurisdicional efetiva.

Para visualizar a situação gerada, a título de exemplo, merece análise o Habeas Corpus n ${ }^{\circ} 96.229$ oriundo da Comarca de Jataí, estado de Goiás, em que, depois de penhorado, levado à praça e arrematado um trator, o devedor, que também era depositário, se desfez do bem, mas teve a decretação da prisão civil afastada pelo Supremo Tribunal Federal.

Mesma situação se passou no $\mathrm{HC}^{\circ}{ }^{\circ}$ 94.491, oriundo da Comarca de Criciuma, estado de Santa Catarina, em que o devedor e depositário chegou a simular um furto na tentativa de frustrar a execução, e, depois de ter visto negados seus recursos junto ao Tribunal Regional do Trabalho e Tribunal Superior do Trabalho, teve sua prisão relaxada novamente pela Suprema Corte.

Ora, é evidente que a prisão, seja qual for a situação, é medida excepcional. No entanto, não se pode esquecer que a prisão do depositário judicial infiel se fundamenta na desobediência de mandamento de direito 
processual ou de direito público, nos termos da distinção proposta no decorrer desse trabalho.

Ademais, diferentemente dos casos de prisão civil envolvendo contratos e obrigações, não possui como elemento essencial a dívida, mas sim a ordem judicial e sua devida observância pelos jurisdicionados. A esse respeito, mais uma vez se mostra acertada a doutrina.

A expressão "dívida" é bastante significativa na locução constitucional, não podendo ser suprimida ou obscurecida para dar azo à sonegação de toda e qualquer retenção civil pelo Estado/juiz, especialmente nos casos em que não está em jogo propriamente disposição de patrimônio, senão a supremacia da Constituição, a dignidade da função judicante e a efetividade da tutela jurisdicional (ACIOLI, 2011, p. 105).

Noutro giro, existem questões que cercam o próprio instituto do depositário judicial, pois o múnus assumido o possibilita exercitar uma função pública mediante cláusulas previamente dispostas na lei, que, no caso de não executadas, trazem a tona o velho problema da ausência sanção o ilícito.

No mais, tal como redigida e interpretada, a Súmula Vinculante $\mathrm{n}^{\circ} 25$ ofende o postulado do artigo $103-\mathrm{A}, \S 1^{\circ}$ da Constituição Federal, já que seu objetivo é unificar o tratamento jurídico a questões idênticas, o que não ocorre na prisão civil de depositário judicial infiel, por possuir fundamentos diversos das outras modalidades de depositário infiel.

[...] ao instituir a impossibilidade da prisão do depositário infiel, qualquer que seja a sua modalidade, a Súmula Vinculante n. 25 do STF engessa a atuação judicial, pavimenta a desmoralização do Poder Judiciário perante a opinião e institucionaliza a atuação abusiva de partes e de terceiros auxiliares no processo, dando azo à ideia geral de que, no Brasil, as ordens judiciais específicas podem ser descumpridas, pois a preferência dogmática para o caso de desobediência de mandados é a cominação de multas pecuniárias e indenização de perdas e danos, as quais, em muitos casos, são infrutíferas e destituídas de qualquer caráter inibitório (ACIOLI, 2011, p.90).

Não menos importante, por não fazer a distinção entre as modalidades de depósito, a Súmula Vinculante $\mathrm{n}^{\mathrm{o}} 25$, ao interpretar o artigo $5^{\circ}$, LXVII da Constituição Federal, extrapola seu texto, condenando à vala comum todas as modalidades de depósito, quando, na verdade, a Magna Carta só veda aquela oriunda de dívida.

Nessa perspectiva, a redação da Súmula Vinculante n. 25 do STF se mostra arbitrária do ponto de vista hermenêutico, na medida em que, 
inexplicavelmente, suprime a expressão "dívida", disciplinando a matéria relativa à prisão civil do depositário infiel de forma genérica, como se aquela locução simplesmente inexistisse na Constituição, o que, ipso facto, torna-lhe inconstitucional, porquanto seu teor vai além do que foi proibido pelo legislador constituinte, imolando os direitos fundamentais de efetivo acesso à justiça e da efetividade da tutela jurisdicional, os quais ficam em um limbo sem qualquer concordância prática com a garantia da liberdade individual (ACIOLI, 2011, p.111).

Desse modo, conforme apontado até então, a súmula vinculante retira do ordenamento jurídico meios coercitivos que poderiam contribuir para a solução do problema do cumprimento das decisões jurisdicionais, e corrobora com o atentado contra a própria dignidade da Justiça.

\subsection{Do atentado à corte: o instituto anglo-saxão do contempt of court}

Um dos aspectos mais interessantes em relação aos argumentos que alicerçam a possibilidade de revisão da Súmula Vinculante $n^{\circ} 25$ e a importância de distinguir com precisão a prisão civil do depositário judicial infiel dos demais casos, é o instituto do contempt of court.

O contempt of court, nos países da comom law, encontra-se dividido em criminal e civil. O criminal funciona após a realização do ato considerado como afrontoso, tratando de punir o ofensor pela prática atentatória. Já o civil tem como função forçar o cumprimento da decisão judicial, funcionando não como punição, mas como meio coercitivo. O contempt of court civil pode ser punido nesses países com multa ou até mesmo prisão (MOREIRA, 2003, p.39).

A origem do contempt of court está associada à ideia de que é inerente à própria existência do Poder Judiciário a existência de meios capazes de tornar eficazes as decisões emanadas. É inconcebível que o Poder Judiciário, destinado à solução de litígios, não tenha o condão de fazer valer os seus julgados. Nenhuma utilidade teriam as decisões, sem o cumprimento ou efetividade. Negar instrumentos de força ao Poder Judiciário é o mesmo que negar sua existência (ACIOLI, 2011, p.30).

Trata-se, portanto, de um instituto que decorre do desacato e desobediência a ordens judiciais, operando como instrumento coercitivo eficaz para garantir a efetividade aos provimentos mandamentais e resguardar o contempt power, isto é, a dignidade do exercício da função jurisdicional. 
O contempt of court, introduzido no sistema processual brasileiro, sobretudo a partir da edição da lei 10.358/01, e denominado em algumas oportunidades de atentatório ao exercício de jurisdição, consiste justamente na adoção de postura do legislador em não aceitar resistências injustificadas às ordens judiciais, e se observa, na prática, por disponibilizar ao julgador instrumentos como a multa e a própria prisão civil.

O sistema jurídico brasileiro abraça claramente a multa como o meio coercitivo por excelência para as hipóteses de contempt of court e de cumprimento das tutelas específicas relativas às obrigações de fazer, não fazer e de entregar coisa, conforme se observa dos arts. 14, V, parágrafo único, 287, $461, \S 4^{\circ}, 461-\mathrm{A}, \S 3^{\circ}, 644$ e 645 , todos do CPC, aproximando-se da disciplina das astreintes do direito gaulês (ACIOLI, 2011, p.32).

É desse instituto que advém, também, a ideia da prisão civil como meio coercitivo, não só do depositário judicial infiel, mas também como tutela específica para satisfazer as obrigações de fazer e não fazer, conforme se infere no artigo 461 e seguintes do Código de Processo Civil.

Merece um exame especial a possibilidade de se aplicar a prisão civil como medida coercitiva inominada, com fundamento no $\S 5^{\circ}$ do art. 461 do CPC. Essa possibilidade vem sendo sustentada por importante segmento da doutrina nacional mais recente. Com efeito, Luiz Guilherme Marinoni, ao comentar o $\S 5^{\circ}$ do art. 461 do CPC, sustenta: "Não é errado imaginar que, em alguns casos, somente a prisão poderá impedir que a tutela seja frustrada. A prisão, como forma de coação indireta, pode ser utilizada quando não há outro meio para obtenção da tutela específica ou do resultado prático equivalente. Não se trata, por óbvio, de sanção penal, mas de privação da liberdade tendente a pressionar o obrigado ao adimplemento. Ora, se o Estado está obrigado a prestar a tutela jurisdicional adequada a todos os casos conflituosos concretos, está igualmente obrigado a usar os meios necessários para que suas ordens (o seu poder) não fiquem à mercê do obrigado (GUERRA, 2009, p.242).

Portanto, admite a doutrina até mesmo a conjugação do artigo $666, \S^{\circ}$ com o artigo 461, $\S 5^{\circ}$ do Código de Processo Civil para fundamentar o decreto prisional do depositário judicial infiel, o que corrobora para o entendimento até então esposado de sua real possibilidade.

Com isso, demonstrado todo o arcabouço lógico-jurídico que fundamenta a viabilidade de repensar da prisão civil para o depositário judicial infiel, resta apenas tecer algumas observações em relação a inexistência de vedação no âmbito das normas internacionais de Direitos Humanos. 
Da inexistência de vedação à prisão do depositário judicial infiel nas normas internacionais de Direitos Humanos

Nesse último espaço, é imprescindível trazer à tela a discussão que envolve as normas internacionais de Direitos Humanos. Isso porque há uma noção difundida e mal fundamentada de que elas vedariam completamente a possibilidade da prisão civil, com exceção dos casos que envolvam obrigações de cunho alimentar.

Antes disso, é necessário perpassar por algumas noções acerca do surgimento e incorporação dos tratados internacionais, bem como o status concedido às suas normas e os critérios utilizados pelo sistema jurídico para enfrentas os eventuais conflitos existentes contra as normas de direito interno.

Do latim tratactatus, de tratare (levar, conduzir, discutir, cumprir, trabalhar), na acepção do Direito Internacional, tratado quer dizer o convênio, o acordo, a declaração, ou o ajuste firmado entre duas, ou mais nações, em virtude do que as signatárias se obrigam a cumprir e respeitar as cláusulas e condições que nele se inscrevem, como se fossem verdadeiros preceitos de Direito Positivo (SILVA, 2005, p.1429).

No Brasil, os tratados são firmados com a assinatura do Presidente da República, ministro das relações exteriores ou terceiro responsável, aprovados pelo Congresso Nacional por meio de decreto legislativo e ratificados, de novo, pelo Presidente da República por decreto executivo, para então serem publicado em Diário Oficial da União.

A questão da incorporação dos tratados internacionais é historicamente problemática. Isso porque não obstante o passar dos anos, doutrina e jurisprudência não chegaram a um ponto comum. Em síntese, o Direito produziu duas grandes teorias que tentam explicar como o tratado passa a produzir efeitos no ordenamento jurídico de um Estado.

A primeira delas, a teoria monista, parte da noção da existência de uma norma superior, pois o direito é um só, quer se apresente nas relações de um estado, quer nas relações internacionais. Ademais, sua doutrina se envereda para dois caminhos: para uns, em caso de dúvida, prevalece o direito internacional, enquanto para outros, prevalece o direito interno (ACCIOLY, 2011, p.235).

Já para os defensores da doutrina dualista, direito internacional e direito interno seriam dois sistemas distintos, que não se confundem. Salientam que o direito internacional depende da vontade comum de vários estados, ao passo que os direitos internos dependem da vontade unilateral. Em consequência, o direito internacional não criaria obrigações para o indivíduo, a não ser que as 
suas normas se vissem transformadas em direito interno (ACCIOLY, 2011, p.235).

Não obstante a corrente humanista defender a incorporação imediata dos tratados, sobretudo aqueles que versem sobre direitos humanos, o que prevalece no Brasil é um sistema que se aproxima do dualismo, por estabelecer a imperiosa necessidade de um processo interno de incorporação.

Incorporado o tratado internacional, surge o problema dos efeitos a ele atribuídos. Possuiria esse o status de lei federal ou norma constitucional? Haveria distinção entre os tratados internacionais que tratem de direitos humanos? Essas questões são turbulentas e o posicionamento jurídico eventualmente se altera.

Em se tratando de tratado internacional que não verse sobre Direitos Humanos, há consenso no sentido de que sua incorporação lhe proporciona efeitos de Lei Federal. A partir disso, estabelece-se que os eventuais conflitos de normas que venham a surgir serão dirimidos de acordo os critérios hierárquico, cronológico e da especialidade, conforme as famosas lições de Teoria Geral do Direito (DINIZ, 2005, 919).

Já no que se refere a tratados de Direitos Humanos, ponto que realmente interessa à discussão, prevalece no Brasil hoje, por força da Emenda Constitucional 45/04 e após o julgamento do Recurso Extraordinário 466.343, de repercussão geral, duas situações.

Pela primeira delas, são consideradas normas constitucionais os Tratados Internacionais de Direitos Humanos aprovados pelo Congresso Nacional de acordo com o rito estabelecido para a Emenda Constitucional e incorporado ao artigo $5^{\circ}, \S 3^{\circ}$ da Constituição Federal pela Emenda Constitucional 45/04, ou seja, aprovação pelas duas casas do congresso, em dois turnos, por três quintos de seus membros.

Já para a segunda, os Tratados Internacionais de Direitos Humanos aprovados antes da Emenda Constitucional 45/04, antes considerados normas infraconstitucionais, passam a fazer parte de uma base intermediária do sistema jurídico, denominada supralegalidade, sendo superiores às leis federais, mas inferiores à Carta Magna, com fulcro em seu artigo $4^{\circ}$, II.

É justamente nesse grupo que se enquadram os principais tratados internacionais sobre o tema da prisão civil do depositário infiel. O primeiro deles, o Pacto Internacional de Direitos Civis e Políticos de 1966, ratificado pelo decreto 592/92, assim institui acerca do assunto:

Art. 11: Ninguém poderá ser preso apenas por não poder cumprir com uma obrigação contratual. 
Na mesma linha, a Convenção Americana de Direitos Humanos de 1969, também conhecida por Pacto de San José da Costa Rica, ratificada pelo decreto 278/92, assim determina:

Artigo $7^{\circ}$ - Direito à liberdade pessoal [...]

7. Ninguém deve ser detido por dívidas. Este princípio não limita os mandados de autoridade judiciária competente expedidos em virtude de inadimplemento de obrigação alimentar.

Ora, a observação atenta dos dispositivos supra que fundamentam a edição da Súmula Vinculante $n^{\circ} 25$ já permitem concluir que a vedação da prisão civil, novamente, se restringe apenas as hipóteses de depósito infiel por dívida, ou seja, obrigações contraídas sob a égide do direito privado, nos termos da própria letra do texto constitucional.

É evidente que a Convenção Americana de Direitos Humanos não veda as prisões processuais de natureza contempt of court, tomadas com fulcro na legislação vigente, pois, nesses casos, não se está em jogo a dívida, mas a salvaguarda da autoridade do Direito, da dignidade do poder Judiciário e dos primados de justiça incrustados no sentimento da sociedade, não estando, portanto, banida do ordenamento jurídico brasileiro a prisão civil do depositário judicial infiel (ACIOLI, 2011, p.58).

Ainda que não bastasse essa situação, conforme recorda MOTA (2007, p. 174), a própria Convenção Americana de Direitos Humanos traz uma série de dispositivos passíveis de sustentar possibilidade da prisão civil do depositário judicial infiel como um meio de buscar a tutela jurisdicional efetiva.

Artigo 22 - Direito de circulação e de residência

3. O exercício dos direitos supracitados não pode ser restringido, senão em virtude de lei, na medida indispensável, em uma sociedade democrática, para prevenir infrações penais ou para proteger a segurança nacional, a segurança ou a ordem públicas, a moral ou a saúde públicas, ou os direitos e liberdades das demais pessoas (grifo nosso).

Artigo 30 - Alcance das restrições

As restrições permitidas, de acordo com esta Convenção, ao gozo e exercício dos direitos e liberdades nela reconhecidos, não podem ser aplicadas senão de acordo com leis que forem promulgadas por motivo de interesse geral e com o propósito para o qual houverem sido estabelecidas (grifo nosso). 
Artigo 32 - Correlação entre deveres e direitos

2. Os direitos de cada pessoa são limitados pelos direitos dos demais, pela segurança de todos e pelas justas exigências do bem comum, em uma sociedade democrática (grifo nosso).

Nesse ponto, é preciso reconhecer que não só não há conflito entre as normas de direito interno e internacional, como estas afirmam a possibilidade de restrição da liberdade de locomoção em prol da satisfação de outros direitos, como é da tutela jurisdicional efetiva, desde que pautada em lei, que no caso é a Constituição Federal, razão pela qual não há sequer razão para se falar em interpretação mais benéfica ao ser humano ou aplicação da regra da proporcionalidade.

Quanto a isso, é forçoso lembrar, em clássica lição propedêutica, que os direitos não são absolutos, e que as normas internacionais de direitos humanos, claramente convergem com as ideias desenvolvidas até aqui, de que o artigo $5^{\circ}$, LXVII só veda a prisão civil ligada à relação de natureza privada.

Não há dúvida de que as exceções contidas no art. $5^{\circ}$, LXVII, denunciam que o legislador está se referindo à dívida no sentido obrigacional, seja de pagar quantia (como no caso do alimentante), seja de entregar coisa (no caso do depositário infiel). Em ambas, perpassa evidente a ideia de vínculo obrigacional que concerne ao devedor, nada se aludindo a hipóteses de descumprimento de relações de direito público em afronta ao ius imperium estatal e a autoridade do direito (ACIOLI, 2011, p.110).

Portanto, não se verificam vedações em normas internas ou de direito internacional à prisão civil do depositário judicial infiel, estabelecida por ordem de órgão judicial por violação à norma de direito processual, de modo que torna se possível, mais uma vez, a revisão da Súmula Vinculante $\mathrm{n}^{\circ} 25$ do Supremo Tribunal Federal, editada em 16.12.09 e publicada em 12.02.10.

\section{CONCLUSÃO}

A elaboração desse trabalho permitiu o conhecimento dos argumentos jurídicos e políticos que sustentam a possibilidade jurídica da prisão civil do depositário judicial infiel e, com isso, a viabilidade da revisão do texto da Súmula Vinculante $\mathrm{n}^{\mathrm{o}} 25$ do Supremo Tribunal Federal.

Para alcançar a referida consideração, teve-se a oportunidade de adentrar o universo da Teoria Geral do Direito e do Processo para identificar, na essência, 
o compromisso assumido pelo Estado com a tutela jurisdicional efetiva ao solucionar os conflitos sociais.

Ainda foi possível delimitar conceitualmente a prisão civil, identificar a evolução do instituto jurídico ao longo do tempo, mesmo que de maneira breve, e estabelecer a devida distinção entre as modalidades de depositário infiel, para bem situar a colocação do tema de modo científico.

A partir dessa distinção, foi possível organizar os casos de prisão civil em dois grupos, quais sejam, em razão de infração à norma de direito material ou de direito privado, e em razão de infração à norma de direito processual ou de direito público, momento em que se colocou e investigou o posicionamento jurídico atual, o da vedação da prisão civil em ambos os casos.

Com isso, adentrou-se no cerne da discussão, ocasião em que se pode constatar que a Súmula Vinculante $n^{\circ} 25$ editada pelo Supremo Tribunal Federal bem caminhou ao vedar a prisão civil em razão de violação à norma de direito material ou de direito privado, em face não só de dispositivo expresso na Constituição Federal, como também em tratados internacionais de Direitos Humanos.

Noutro giro, se verificou ainda que a prisão civil em razão de infração à norma processual ou de direito público, caso do depositário judicial infiel, é juridicamente possível, seja por inexistir qualquer conflito ou colisão com normas de direito interno ou externo, seja por possibilitar a utilização de um instrumento que vai de encontro com a busca pela tutela jurisdicional efetiva, o que, respeitosamente, oportuniza até mesmo repensar a mencionada súmula vinculante.

\section{REFERÊNCIAS}

ACCIOLY, Hildebrando; SILVA, G. E. do Nascimento; CASELLA, Paulo Borda. Manual de Direito Internacional Público. 19. ed. São Paulo: Saraiva, 2011.

\section{ACIOLI, José Adelmy da Silva. A possibilidade da prisão civil do} depositário judicial infiel. São Paulo: LTR, 2011.

ALVIM, José Eduardo Carreira. Teoria Geral do Processo. 11 ed. Rio de Janeiro: Forense, 2008. 
CINTRA, Antônio Carlos de Araújo; GRINOVER, Ada Pellegrini; DINAMARCO, Cândido Rangel. Teoria Geral do Processo. 25 ed. São Paulo: Moderna, 2009.

DICIONÁRIO JURÍDICO BRASILEIRO. Prisão. Disponível em: < http:// www.facape.br/anderson/ied/Dicionario_Juridico.pdf $>$. Acesso em 06 de Julho de 2012.

DINIZ, Maria Helena. Dicionário Jurídico. 2. ed. São Paulo: Saraiva, 2005. Vol. 1.p. 919.

DINAMARCO, Cândido Rangel. Instituições de Direito Processual Civil. 4 ed. São Paulo: Malheiros, 2002.

FREITAS, Amanda Leite. A prisão civil do responsável pelo inadimplemento voluntário e inescusável de obrigação alimentícia na justiça do trabalho. Disponível em: $<$ http://www.webartigos.com/artigos/aprisao-civil-do-responsavel-pelo-inadimplemento-voluntario-e-inescusavel-deobrigacao-alimenticia-na-justica-do-trabalho/42619/>. Acesso 26.06.12

GUERRA, Marcelo Lima. Execução Indireta. São Paulo: Revista dos Tribunais, 1999.

MARINONI, Luis Guilherme. Teoria Geral do Processo. 4 ed. São Paulo: Revista dos Tribunais, 2010. vol. 1.

MOTA, Lise Nery. Prisão Civil como técnica de efetivação das decisões judiciais. Rio de Janeiro: Lumen Iuris, 2007.

MOREIRA, Alberto C, et all. Nova reforma processual civil. São Paulo: Método, 2003.

PANCOTTI, José Antônio. Institutos Fundamentais de Direito Processual: Jurisdição, Ação, Exceção e Processo. São Paulo: LTR, 2002.

QUEIROZ, Odete Novais Carneiro. Prisão Civil e os Direitos Humanos. São Paulo: Revista dos Tribunais, 2004. 
ROSA, Felippe Augusto de Miranda. Sociologia do Direito: O fenômeno jurídico como fato social. 18 ed. Rio de Janeiro: Zahar, 2009.

SÁ, Leo Mauro Ayub de Vargas; SANTOS, Marcos Wasum. A prisão civil no ordenamento jurídico brasileiro. Disponível em: $<\underline{\mathrm{http}}$ :/www.ambitojuridico.com.br/site/index.php?n_link=revista_artigos_leitura\&arti go $\mathrm{id}=6375>$. Acesso em 26.06.12.

SOUZA, Rafael Martin Carreño de Paula. A (in)constitucionalidade da súmula vinculante $\mathbf{n}^{\circ} \mathbf{2 5}$ do Supremo Tribunal Federal. Disponível em: $<\underline{\text { http://intertemas.unitoledo.br/revista/index.php/Juridica/article/viewArticle/ }}$ $\underline{2865}>$. Acesso em 26.06.12.

SANTOS, Moacyr Amaral. Primeiras linhas de Direito Processual Civil. 25 ed. Belo Horizonte: Del Rey, 2008. Vol 1.

SILVA, José Milton. Teoria Geral do Processo. 2 ed. Rio de Janeiro: Forense, 2003.

SILVA, Oscar Joseph de Plácido e. Vocabulário Jurídico. 26.ed. Rio de Janeiro: Forense, 2005.

Recebido em: 14/08/2012 Aprovado para publicação em: 16/04/2013

Como citar: OLIVEIRA, Douglas Henrique de; TACLA, Sílvia Regina. Reflexões acerca da Possibilidade da Prisão Civil do Depositário Judicial Infiel e Tutela Jurisdicional Efetiva. Revista do Direito Público, Londrina, v.8, n.1, p.189-214, jan./abr.2013. DOI: 10.5433/1980-511X.2013v8n1p189. 